AperTO - Archivio Istituzionale Open Access dell'Università di Torino

\title{
Europeanisation of Citizenship within the EU: Perspectives and Ambiguities
}

\section{This is the author's manuscript}

Original Citation:

\section{Availability:}

This version is available http://hdl.handle.net/2318/82213 since

Publisher:

Jean Monnet Series of Working PaperCenter of Excellence/Trento University

Terms of use:

Open Access

Anyone can freely access the full text of works made available as "Open Access". Works made available under a Creative Commons license can be used according to the terms and conditions of said license. Use of all other works requires consent of the right holder (author or publisher) if not exempted from copyright protection by the applicable law. 


$$
\text { WP S.S } 2008 \text { n. } 2
$$

\section{Patricia Mindus}

Department of Political Studies University of Turin

EUROPEANISATION OF CITIZENSHIP WITHIN THE EU:

Perspectives AND AMbiguites

() Patricia Mindus 


\title{
Europeanisation of Citizenship within the EU:
}

\author{
Perspectives and Ambiguities
}

\begin{abstract}
:
The citizen is the "simple element of a polity", as Aristotle once put it. Citizenship appears as a prolegomenon to other core questions concerning public policy and constitutionalism. In Europe today, we deal with a threefold concept of citizenship and we need to understand how it is built up in order to assess some recent trends in citizenship, third country national status and civic participation. More than fifteen years after the "complementary status" of European citizenship was introduced into the "Ufo" of the Union, we should ask what EU citizenship means today for the ongoing Europeanisation process of our societies. The thesis is that the three models today merging in EU citizenship can be accounted for by looking at the opposite of citizenry: By emphasizing inclusiveness, the sociological focus is on the marginalised subject, migration and asylum policies. Law and jurisprudence look at citizenship by trying to limit the numerous hard cases arising in a world of migration where the opposite of the citizen is still the alien. The political model holds the subject (sujet) in opposition to the citizen (citoyen), entailing problems related to the democratic quality of EU institutions. These different standards tend to overlap in the current debate and this engenders misunderstandings. The Lisbon Treaty should be addressed from this viewpoint: at what level do we find innovations and how can these be inserted into a coherent framework? As a result of the erosion of traditional nationality, we now face a legal patchwork, which produces an array of hard cases. Building on a strong philosophical tradition, I suggest a possible method for bridging these three standards and for highlighting the current ambiguities that EU citizenship has entailed for those living and working in Europe who lack the ius soli and ius sanguinis-based entitlement. By looking at the perspectives and the ambiguities of the EU citizenship status today, the aim is to shed new light on transnational citizenship-building.
\end{abstract}

(Keywords: Europeanisation - EU citizenship - Nationality - TCN-status - Rule of Law - Civic participation)

Introduction

1. State-of-the-Art

2. Three Standards on Citizenship

2.1. The Political Standard

2.2. The Jurisprudential Standard

2.3. The Sociological Standard

2.4. Basic Issues

3. Overlapping Standards: A Source of Difficult?

4. Erosion of Nationality: A Legal Patchwork

5. Towards Residence-based Entitlement?

6. Bridging the Models: A Comprehensive Framework

7. A Functional Device For Social Analysis

Concluding Remarks 


\section{Introduction}

In 2008, sixteen years after the "complementary status" of European citizenship was introduced into the still airborne "Unidentified political object" of the Union, it is about time to ask what kind of status this reform has entailed. It is indispensable to recognize that the nature of citizenship still functions as a prolegomenon for answering other pressing questions: How can cross-national rights be guaranteed in the context of migration, if citizenship is equivalent to sharing fully in the social heritage of national identity? How can social integration be enhanced through transnational public services if for example third country nationals or the stateless are kept out of the system? How can active participation among European citizens be promoted, if citizenship is viewed only as a formal legal status distinct from the democratic quality of EU institutions? Last but not least: What does EU citizenship mean today for the ongoing Europeanisation process of our societies? The current challenges of EU citizenship are becoming tougher, in part, because the model it is supposed to embody still presents indistinct features.

What is usually stressed, within and across Europe, as a prerequisite or conditio sine qua non of Europeanisation is "the participation of its citizens in the European integration process" (Olsen 2002, Radaelli 2004, Delanty, Rumford 2005). The aim of this essay is thus to take a step back and ask: What do we mean by this? Who participates in the citizenry? I suggest that the macro-mode of analysis is useful in this context: the very notion of citizenship needs to be unpacked in proper detail and from as many different points of view a possible. Unless we are content to regard the somewhat abstract, vague and fourre-tout level of discussion as the default position, we need detailed analysis into the concept and an empirical investigation into its various modes of utilization in our discourses.

It is often suggested that «"Europe" is generically complex, ambiguous, and difficult to grasp; likely to be defined differently by different people and institutions from their own distinct points of view» (Jenkins 2008: 154). This might be true as far as the multifaceted notion of "Europe" is concerned (af Malmborg, Stråth 2002, Ifversen 2002), but does this mean EU citizenship is condemned to obey the same fuzzy logic? Would the citizens in and of Europe not celebrate a better understanding of their status? Here I shall not directly address the issue of "European identity" as a (new?) symbolic realm of "agents of consciousness," nor a mode of discourse in which the process of "selfing" and "othering" takes place, even though it should be kept in mind that European citizenship, by virtue of its own name, entails such an outlook. Nor do I discuss the so-called no-demos thesis, which regularly 
comes up in citizenship related discussions at least since the Grimm-Habermas debate in the 1990s (and more recently in Offe, Preuss 2006). Rather, I will argue from the starting point that this very idea European citizenship - unfolds in the transition from the traditional nation-states to what is often labelled the post-sovereign state, grounded in transnational citizenship building.

After almost two decades of intense debate, and of EU case law on citizenship, we are now dealing with a threefold concept: political, legal and social. We need to understand how it is built up in order to test some recent trends in citizenship, third country national status and civic participation. The three standards today merging in EU citizenship can be adequately explained by looking at what is opposed to citizenry. Yet, analysing these three standards is not enough to clear the ground of unwarranted conclusions. We still need to bridge the different standards. I suggest this might be possible by using a specific theoretical paradigm, taken from philosophy. By building on this framework, a series of problems that have been emerging during the last fifteen years find a more reasonable assessment. This enables us to evaluate the current development of EU jurisprudence, which is departing from some basic standards in international law, such as the effectiveness principle, in order to grasp why this is becoming highly problematic in a world of migration. It gives us a better understanding of the complex mechanisms regulating the nationality laws in EU27. The suggested framework provides a counterfactual grid, which is helpful when we deal with significant issues on the political agenda, like the denationalisation process of citizenship for instance.

This essay is presented in seven sections: the first three focus on the theoretical perspective. We shall first have a look at the state-of-the-art in today's debate on citizenship and thereby appraise the different standards that prevail in the various disciplinary fields (section 1). Attention will be directed foremost to political, legal and social sciences. I suggest that we are now dealing with a threefold concept of citizenship (section 2). Then we shall look at how elements taken from the various standards are being merged together in a somewhat undifferentiated way, which might lead to further misunderstandings (section 3). Particular emphasis will be laid on some hard cases arising from art. 20 of the Consolidated versions of the Treaties (ex. art. 17 TUE) (section 4); and recent trends toward residency-based entitlement will thus be taken into consideration (section 5). Finally, a comprehensive paradigm for bridging the previous standards is proposed and we shall see how it can be used to examine the practical issues of the present day (section 6). Therefore, the aim is not only to analyse scholarly work, but also to design a functional device for facing an array of questions that citizenship raises in today's complex society (section 7). 


\section{State-of-the-Art}

Citizenship has become a very popular topic generating a complex and articulated debate that has grown significantly over the last fifteen years. Some estimate that over $50 \%$ of all scholarly literature has been published since 1990 (Isin, Turner 2002: 9).

As known, much of the contemporary debate on citizenship was stimulated by the work of the British sociologist Thomas Humphrey Marshall (1893-1981), who intended citizenship as our fully belonging to the community (Bulmer, Rees 1996). By assuming that citizenship is the status conferred on those who are full members of a community, Marshall's idea was to use citizenship as a tool in order to strike a balance between entitlements and provisions (Dahrendorf 1988), allocative and integrative requirements of society (Turner 1993). Perhaps, it should be added that Marshall's landmark in social sciences, Citizenship and Social Class from 1949, did not really obtain any significant attention until 1963, when the editor Heinemann made it into the central piece in Sociology at the Crossroads and, more specifically, after the T.H. Marshall Memorial Lectures, organised by the University of Southampton in the early Eighties. So it really is a quite recent field of study.

Moreover, a common feeling among scholars has pointed to the necessity of adopting an interdisciplinary approach to citizenship research. Until a few years ago not a single line on citizenship was generally found in handbooks, encyclopaedias and dictionaries dedicated to political thought or to social sciences (Sills 1968; Boudon 1982; Borgatta 1992). Thomas Janoski could still claim in 1998 that «although citizenship is the lingua franca of socialization in civic classes, as well as the cornerstone of many social movements seeking basic rights, and a key phrase in speeches by politicians on ceremonial occasions, oddly enough, citizenship has not been a central idea in social sciences» (Janoski 1998: 8). Since the late Nineties, however, scholars have increasingly directed attention towards interdisciplinary perspectives covering the fields of politics, sociology, history and cultural studies that move beyond conventional notions of citizenship. So today, citizenship is often analysed in the context of contemporary processes involving globalisation, multiculturalism, gender, changes to the state and political communities. But all this is very recent and we should not forget that the prevailing view has been another.

The customary legal perspective holds citizenship unequivocally to be the status conferred on those who are entitled to various active and passive positions in relation to the State. An emblematic way of putting it is to use the German wording for citizenship, Staatsangehörigkeit. The legal standard 
of citizenship has roots in Roman law, where civis is a status indicating the way in which a person is connected to the legal order (Sherwin-White 1939). This standard is still the focus of most legal scholars and practitioners and it pivots around the idea of "belonging to the State," "pertinence to State territory," or - in Hans Kelsen's phrase - it is equivalent to "the personal sphere of validity of the legal order." This viewpoint is, in fact, an heir of the modern political and legal world centred on sovereignty and nationality. In the long history of the legal civis, the problem of entitlement has been connected to the extension of the legal order and its homogeneity. The aim was to avoid, as much as possible, an "uncertain" legal space. This is basically the very same problem Jean Bodin tackled with his theory of citizenship in Six livres de la République (I, 6) in 1576, where «the citizen is nothing but the free subject under sovereignty» (Bodin 1977: 68). And it represents the core issue of the first modern case on nationality: the Calvin's case from 1608 (Price 1997).

It is precisely this customary outlook that has started to disintegrate. Its definition of citizenship is historically inadequate because it ignores the much older roots of citizenship that developed in ancient city polities long before the era of state sovereignty, but it is also inadequate today because it blinds us to the many ways in which citizenship as nationality is challenged by globalization, transnational migration, and minority nationalism and, of course, Europeanisation. In the last century, legal positivism, in its monistic and formalist tendencies, tried to establish a bi-univocal correspondence between the legal order and "its" citizens, following a status conferred by positive law, defined by the sovereign state. This provoked the collapse of an already worn-out model which could no longer uphold its ratio essendi, i.e., to avoid the multiplication of incompatible legal positions imposed on the same human being. Indeed, the "Hobbesian" anarchy of international relations leaves little or no room for overarching legal agreements, such as the Convention of the Hague signed on the $12^{\text {th }}$ of April 1930 on the limitation of statelessness, or the U.N. Convention on the citizenship of married women, signed on the $29^{\text {th }}$ of January 1957 in New York. The main instrument for preventing potential conflict is still constituted by bilateral treaties. By accentuating the vacuity of the citizenship category - susceptible to being filled with a great variety of content, rights and duties, while the only constant attribute seems to be subjecthood to the legal system - the traditional conception of citizenship paved the way for an international disorder in which migration questions the state's sovereign right of defining its own citizens. In other words, the customary legal perspective on citizenship provokes perverse effects, like the increase of statelessness and multiple nationalities, besides from new phenomena like the so-called "legal tourism," a kind of "forum shopping" where free movement enables people both to avoid compliance with rigid national regulations in areas such as bioethics, and to declare residency in legal systems where taxes are less burdensome. 
The crisis of the conventional legal standard also brought about the contemporary debate. It is warranted to speak of a debate, notwithstanding the different disciplinary provenances and conflicting views. A common feature that can be recognized in most citizenship studies is the target of their criticism: That is, the way citizenship found systematisation in modern legal thought. To be accurate, criticism predictably has also been directed to Marshall's account (Giddens 1982; Barbalet 1988; Mann 1996). But what really seems to have disconcerted scholars is modern legal thinking. This latter systematization is frequently accused of reducing citizenship to a void legalism, a dull administrative inscription and a cold technical status. Therefore, the point of much citizenship research is basically to reassert the very opposite of Berthold Brecht's sarcastic claim: «the passport is the most noble part of Man.»

Yet, the understanding of citizenship often lingers on more traditional assessments, characterised by clear-cut disciplinary divides. The result has been that attempts to bridge the various perspectives at hand continue to meet increasing difficulties. In fact, legal scholars hardly ever take into consideration sociological case-studies, while political scientists turn a blind eye to issues addressed in international private law and so on.

Furthermore, this disciplinary entrenchment has boosted the side-effect of deepening misunderstandings. Legal scholars insist that the «sociological concept of citizenship is totally unsatisfactory» (Costa 1999: 48) or that «sociological studies on citizenship programmatically ignore positive law (...) resulting in a generic inclination towards Natural Law» (Ferrajoli 1999: 275). On the other side of the fence, legal scholars are accused of retrospective arguing so that «legal definitions of citizenship seem to short-circuit citizenship because they remain the realm of passive rights and do not extend into active rights of political and social democracy» (Janoski 1998: 238).

Nonetheless, the scholastic and puerile attempt to keep one's academic field to oneself cannot be held to be especially worrying. Of greater weight are some of the misinterpretations embedded in the debate, which seem to be far too common on both sides of the fence. Certainly, all the emphasis laid on citizenship has brought the notion into the limelight. However, there are some negative effects linked to this evolution.

Broad definitions tend to describe "citizenship" as all kinds of membership-related entitlements and obligations in social groups and organisations, such as economic corporations, kinship networks or civil society associations. This leads to a conceptual overstretch that deprives citizenship of its essentially political meaning. Moreover, the limelight on citizenship has also contributed to loosening up the fundamental difference between status civitatis and status personae. In the current debate, the two figures of citizenship and personhood seem to be exceedingly confused. An interesting statement is 
for example that T.H. Marshall's account on citizenship is «probably the most influential (...) interpretation of the development of human rights» (Bellamy 1994: 239). Such claims usually make lawyers blush: Human rights are granted to all human beings, not to citizens of any given state. There seems to be a very peculiar form of inflation behind this blurring of genres, which consists of trying to entitle the citizen to a long list of rights, which in reality has a quite different basis, namely the person as such. This is why it is important to clarify the conditions enabling a specific right to be plausibly referred to the category of citizenship.

One of the major problems for the citizenship scholar is that the disciplinary entrenchment and embedded misconstrual has led to the current situation: We lack a comprehensive model for understanding citizenship, which consequently brings about a failure to cope with pressing and urgent questions, especially when it comes to civic participation, denationalisation-trends and civil societybuilding.

\section{Three Standards on Citizenship}

The outcome of the contemporary debate may be defined in terms of a threefold concept of citizenship. We need to understand how it is built up in order to evaluate new proposals. Scholars have recently claimed that the models of citizenship should be distinguished into a discretionary element (citizenship-as-belonging sustained by communitarians), a decisional aspect (citizenship-asparticipation advocated by republicans), and an allocative dimension (citizenship-as-rights prioritis ed by liberals) (Bellamy, Castiglione, Shaw 2007, pp. 5-7). However, such a distinction does not take into account all the disciplinary fields involved in citizenship studies (leaving out comparative and EU law for example). Moreover, it is grounded on currents in political theory that have increasingly been criticised. My suggestion is therefore a different tripartite solution. It is based on the idea that the standards merging in today's EU citizenship framework can be properly explained by looking at what is opposed to citizenry.

This way, three different semantic areas emerge, each of which is grounded in a specific dichotomy with two variables: content and structure. Each semantic area, in turn, corresponds to the prevailing disciplinary viewpoint: political, legal and social sciences. The basic dichotomies are the outcome of different kinds of problems, which ought to be kept distinct, even though they do not lack connections or links overall. Here, I will present these three standards or models in a chronological order, based on their evolution in history. 


\section{The Political Standard}

The political standard or model for assessing citizenship is grounded in a dichotomy which opposes the citizen to the subject or, in the traditional terms of the French Revolution, the citoyen and to the sujet. On one hand, the citizen is therefore the active member of the state, who contributes to the formation of collective will or self-government, by making decisions (in the classic form of direct democracy) or by voting for representatives (in modern representative democracies). On the other hand, the subject is the passive member of the political community who does not participate in the shaping of the law and in collective decision-making. But s/he is nonetheless subject to the laws that others - i.e., the citizens and/or their representatives - have chosen. It should be stressed that this distinction does not correspond to that between citoyen actif and citoyen passif, which became popular with Sièyes in $18^{\text {th }}$ Century France. As a matter of fact, it has a different origin and can be traced back to Aristotle's theory of citizenship in the third book of Politics (Düring 1974; Johnson 1984; Mossé 1993). In the modern world, this political conception of citizenship regained popularity with the French revolution (Rosanvallon 1992), although it started to overlap, at least to a certain extent, with the idea of "nationality" in the same period (Colas 1991; Brubaker 1992; Guiguet 1999). The problem this model deals with concerns deliberation and decision-making with erga omnes validity within a certain territory. On a deeper level, this standard aims to respond to the question of legitimacy.

Today, the problem of extending political rights to non-nationals residing within the state - an issue which has been appearing regularly on political agendas all around Europe - corresponds to this political model and it attempts to answer the central questions of legitimacy and political obligation. This is an open issue that EU citizenship still faces (Köchler 1999). For example, we might mention the 800000 Poles now living in the UK. From the political citizenship standard, this recent migration wave poses serious problems. First, these people retain their right to vote in Poland even though they do no longer live there. However, they only have a limited access to political rights in the host country. Secondly, the possibility of a double vote for the same scrutiny of in EP (European Parliament) elections, which is left unsanctioned in Europe, jeopardis es the principle of one man, one vote (Garot 1999). This political model also encounters serious problems in some new member states that joined in May 2004: Since 2001, Hungary, Slovenia, and Slovakia have introduced so-called status laws, which create a quasi-citizenship status for external minorities held to belong to a larger cultural nation. In December 2004, a referendum for introducing dual citizenship for up to 3 million ethnic Hungarians in 
Romania, Slovakia, and Serbia was defeated because of low turnout. If it had won, this initiative would not merely have exacerbated international tensions but could also have led to external voting rights and a permanent majority for nationalist parties in Hungarian elections: A political "twist" to what many see as a problem of a merely legal nature.

\section{The Jurisprudential Standard}

The jurisprudential standard, to which some reference has been made, is also based on a rigid dichotomy - aut aut - opposing citizens to those who do not belong to a given legal order. The citizen, who in modern times has come to be the equivalent of the national since the legal order has assumed a national and sovereign nature, is opposed both to the alien and the stateless (Krajewski/Rittstieg 1986, Lagarde 1997, Preuss 2003). There is no room in this model for in-betweens. Here, the citizen is not active but only passive: s/he may or may not be granted enfranchisement without any substantive change in the model. Actually, the construction is purely formal and can hence incorporate most contents (Kelsen 1929; Kelsen 1945). This is also why it is compatible with most political regimes, regardless of the democratic tenure or the constitutional framework. This conception of citizenship or Staatsangehörigkeit became predominant with the rise of the modern state. I have already cited Jean Bodin and Calvin's case that was commented on by Francis Bacon and Edward Coke. The fully developed theory of citizenship in Jurisprudence can be found in the German public law scholars from the $19^{\text {th }}$ century. The problem this model deals with is certainty or rule of law, as opposed to arbitrary, random and unpredictable rulings. The reason Jurisprudence developed this citizenship apparatus is to avoid the multiplication of so-called hard cases, where incompatible yet judicially relevant positions are ascribed to the same individual (Verwilghen 1999). Most bilateral treaties in international private law tend to avert that specific situation, as well as international agreements (Marakov 1962; Bauböck 2006). Even if the legal model has met with harsh criticism as being a "recipe for chaos" (Bauböck 1997) in a world of migration, it does not mean that the problem the model addresses has been resolved. It only implies that the means, through which Jurisprudence hoped to solve the issue, have failed.

Today, the problem addressed by the legal citizenship standard has not yet been worked out and it is still tangible in relation to Europe and EU citizenship. From this viewpoint, it suffices to mention statelessness, where the person deprived of nationality becomes judicially "invisible," a condition which entails other problems in accessing rights. It is not uncommon that wedlock and marriage 
contracts are inaccessible for stateless individuals. In Europe, a case of mass statelessness can be found for instance in Estonia, which has signed neither the 1954 Convention relating to the status of stateless persons, nor the 1961 Convention on the reduction of statelessness. When Estonia joined the Union on May $1^{\text {st }}$, 2004, around 160000 Russian-speaking persons were still stateless, that is around 12 percent of the total population. It should be added that Estonia's stateless persons decline every year and currently only 9 percent of residents are carrying so-called grey passports, compared to 32 percent just 15 years ago. But the figures are still eloquent. A significant number of refugees also end up in a similar situation (Marrus 1986), since they cannot «avail themselves of the protection of the government of the country of their nationality», following the International Convention on the Reduction of Statelessness from 1961. Likewise, in Slovenia, bureaucratic obstacles for the acquisition of citizenship by persons originating from other Yugoslav republics created at least 18000 "erased" individuals, who were transferred from the registry of permanent residents to that of foreigners (Bauböck 2006; Shaw 2007).

\section{The Sociological Standard}

According to the sociological standard, which is the most recent, the content of its basic dichotomy varies, as well as its structure. The opposite of the citizen is neither the subject as in the political model, nor the foreigner (alien/stateless) as in the legal model of citizenship. Rather, it is the marginalised individual or the excluded person, as developed by Robert Ezra Park (Park 1928) and Gino Germani (Germani 1973). Grounded in T.H. Marshall's description of the three categories of rights (civil, political and social) for which the citizen has struggled in modern times (Marshall 1950), the sociological model does not rely on a rigid dichotomy, but on a gradualist one. This means that we can point to intermediate positions in between maximal exclusion and full integration in society. This latter condition thus becomes the equivalent status of civis optimo iure. This gradualist element has led to the development of a vocabulary using expressions such as "limited" (or hyphenated) citizenship" that do not belong to the other models or standards. The key-problem, to which the sociological approach applies, is, of course, social cohesion (Turner 1993).

The fact that Europe continuously presents urgent dilemmas of this latter type hardly needs lengthy explanations. The social citizenship standard is often challenged: As part of transnational arrangements attendant upon recent enlargements, for example, there is effectively a hierarchical grading of such a membership, in that nationals of more recent members have differentiated access to the labour markets 
of some long-standing members. Restrictions in the labour markets of the EU15 for Eastern Europeans were introduced after the 2004 and 2007 enlargements, with the exception of the UK, Ireland and Sweden, under the threat of the "Polish plumber" (Recchi 2005, 2006). This should be viewed against the background of empirical evidence: Jürgen Gerhards recently stressed that the idea of nondiscrimination, at the heart of the policy for increased social cohesion, is not supported by the majority of the European citizens: «by analyzing the data from the European Values Survey, we showed that the majority of European citizens still prefer a nationally bounded conception of access to the labour market. The majority of interviewees rejects the idea of equal opportunities for nationals and European foreigners on the job market» (Gerhards 2008: 135). This is not the only breach we find in social cohesion when we look at the European Values Survey (Arts, Halman 2004; Mindus 2006). However, it is an increasing concern for EU policy makers in the wake of the activism against the Bolkenstein directive and recent jurisprudence of the ECJ in the cases Rüffert, Viking Line and Laval.

\section{Basic Issues}

In today's debate, these three different standards - political, legal, and social - continue to live side by side. They offer different perspectives on citizenship and lay emphasis on different fundamental problems. Obviously, "different" does not mean "incommensurable" and the basic issues - legitimacy, rule of law, and social cohesion - are all unquestionably necessary elements for enabling peaceful living. Yet, we should not forget that, in accordance with the problematic field of investigation one chooses, the type of "citizenship" varies and so do procedures and methods for acting in response to the problem. For instance, by promoting deeper social integration in Europe, the so-called "democratic deficit" of the Union's institutions will not be resolved.

It is telling that the symposium organised in late April 2007 by the European Council on edemocracy stressed the importance of engaging citizens in decision-making by calling on ecampaigning and social networking. Such practices are certainly crucial for developing preconditions of democracy like public opinion, converging transnational media policies, etc. These are all issues that are being assessed from the sociological viewpoint, focusing on inclusive citizenship. These topics are certainly important. However, they remain logically distinct from, say, improving accountability of the institutions, enhancing vote-participation in Parliamentary elections, reducing levels of concurring norms or simplifying the treaties and EU-law, which are instead core issues for the political model (Shaw 2007). 
Another example is the justification of the European Council for introducing art. 19 into TEC (now art. 22 in the consolidated version) which grants the right to vote and stand in local and EP elections. These political rights were presented as «an application of the principle of non-discrimination between nationals and non-nationals and a corollary of the right to free movement and stay declared in the Art. 8 of the Treaty» (see the two directives 93/109/CE of the $30^{\text {th }}$ of December 1993, GU L $329 / 34$ and 93/109/CE of the $6^{\text {th }}$ December 1993, GU L 368/38). Now, what kind of citizenship would plausibly explain why voting should be a "corollary to free movement" and promote integration? Neither the political standard, nor the legal one. Keeping these examples in mind, my suggestion is therefore that we need to dissect these three distinct standards so we can stress inconsistencies in order to find adequate solutions for specific purposes.

\section{Overlapping Standards: A Source of Difficult?}

The interpretation (and wording) of some articles on EU citizenship has evolved over the last decade. Part of this development has not been celebrated by legal scholars since it is considered a source of confusion. It is striking that this evolution seems to introduce the "sociological standard" on citizenship into the legal discourse on EU citizenship.

The personal scope of the right to petition (ex art. 21.1 now art. $24 \S 2$ and ex art. 194 TEC now art. 227), the right to apply to the ombudsman (ex art. 21.2 now art. $24 \S 3$ and ex art. 195 TEC now art. 228 ) and the right to free movement (ex art. 18 TEC now art. 21) has undergone significant change. An often overlooked novelty of the Nineties on EU citizenship is that applying to the ombudsman or petitioning the Parliament in Strasbourg was initially among the rights of the EU citizen. Today, these rights are not limited to Union citizens, but granted to all natural and legal persons lawfully resident within the Union. In the Nice Charter these rights were included under the title V Citizenship, even though they were no longer benefits related to the status of EU citizenship. This leads to a paradox: As these rights were extended to all persons and no longer linked to the status civitatis, EU citizens were stripped of a privilege!

Another innovation of the Nice Charter was to extend the personal scope (rationae personae) of the right to move and reside freely within the Union to include all persons, and hence to disconnect access to free movement from the status of EU citizens. A similar reasoning could be extended to the right of access to documents, deriving from the principle of transparency that Scandinavian Member States in particular prioritise. However, this right is not expressively listed as a citizen's right. Likewise, the 
formal right to good administration, granted in art. 41 of the Charter of Fundamental Rights, makes no explicit mention of any nationality or residence restrictions.

Without discussing the legal relevancy of the Nice Charter, what should be noticed is that while extending the personal scope of art. 18 on free movement to all persons, three categories still remain excluded: citizens of member states without social insurance or equivalent economic resources, individuals who have been convicted for offences against public order or safety, and Third-Country Nationals (TCNs) legally resident in a single member state (Nascimbene 1995; Dollat 1998; Giubboni 2007). What I would like to stress is that the lexis of social citizenship as integration has its "legal" fall out in the fact that a right explicitly extended to all persons appears under the title "citizenship" in the Nice Charter, and not, for example, in the European Convention for the Protection of Human Rights. Some additional grounds for confusion and misunderstanding arises from the inclusion of these rights granted to all residents - in the part II of the Constitutional Treaty (as part of the text of the Charter of Fundamental Rights). This ambiguity of including rights of all lawful residents under the part II's "nondiscrimination and citizenship" is repeated in the Lisbon Treaty and in the Consolidated versions of the Treaty on European Union and the Treaty on the Functioning of the European Union (OJEU C 155/52, 9/5/2008). This ambiguity can potentially lead to further inconsistencies. Here, it suffices to mention the wording of art. I-3(2) of the Constitutional Treaty that has been widely criticised because it declares that the Union shall offer an area of freedom, security and justice to its citizens (only?).

Another case of overlapping standards is the rationale of the right of EU citizens to vote and stand in local elections, art. 22-1 (ex art. 19.1). The argument has been that admitting participation in local elections would strengthen integration for EU citizens living in a member state from which they are not ressortissants. This has been a recurrent argument ever since the Delhousse project in the Sixties and the Spinelli project from 1984. Inadvertently, this led to the failure of arguing why these very EU citizens should not be admitted to national elections. The (convincing) counterargument was that admission to national elections would enhance integration even more. Besides some technicalities mostly used in France where municipal elections can be considered administrative and hence not political, it became harder to argue against political participation of EU citizens resident in other member states. This is also why the decisions in the early Nineties by the German Supreme Court, i.e. the Bundesverfassungsgericht, restating an exclusively German suffrage met with so much criticism. However, some Member States had already allowed alien suffrage like in the cases of the UK, Ireland, and Spain (usually on the basis of reciprocity). A rhetoric use of the social standard, when the political model would have been more appropriate, provoked the current ambiguity and stalemate in liberalising the franchise. 
The question of extending the franchise to local and/or national elections is not merely a question of "social integration" (which can be the outcome of a paternalistic decision- making), as much as it is a question of legitimacy (which cannot be simply auctroyé). So, if enhancing social integration is posited as an objective, a viable way to achieve it is probably not so much the extension of political rights and enfranchisement as, say, job placement or adult education. For instance, we have convincing empirical data for claiming that inter-European migration promoting policies furthers Europeanisation in so far as they, indirectly, enhance perceived legitimacy while deepening integration (Recchi 2008). In other words, the right to vote as a tool for the advancement of equal treatment has severe limitations.

Another recent case of hybrid application of various citizenship standards can be found in the Charter of e-Rights, adopted by the Eurocities Group in June 2005. All the rights mentioned are ascribed explicitly to the EU citizen. Yet the objective that the Charter declares to pursue is to reduce the so-called digital divide. It is clear that the digital divide, whether in access or use of erelated technology, is not linked to status civitatis. Rather, it is a social problem afflicting various and heterogeneous groups within the EU. Again, the legal designation is used for a purpose that cannot be adequately handled with such (ambiguous) tools.

\section{Erosion of Nationality: A Legal Patchwork}

In the making of the EU citizen, some elements tended to deviate from the traditional legal model, based on the principles of ius soli and ius sanguinis. In Léo Tindemans report on special rights from 1974, one of the first steps towards the creation of EU citizenship, emphasis was consciously laid on the fact that EU citizenship had to be built in avoidance of the so-called principle of naturalisation, i.e., the loss of citizenship of birth and acquisition of the citizenship of the host country in case of interEuropean migration. Nevertheless, evidence shows that this break with the traditional legal model has been partial and weak.

In fact, the trend towards toleration of dual nationality in general (intra- or extra-European migration alike) is not without exceptions: Austria, Denmark, Germany, the Netherlands, and Luxembourg in EU15, for example, still require that the previous nationality must be renounced in naturalisations, although many exceptions are made in Germany and in the Netherlands, while Luxembourg is considering abolishing such a condition. In Germany, the Red-Green coalition failed in 1999 in its attempt to include dual citizenship in its reform of naturalisation. 
The stronghold of the long-established legal standard also shows in the art. 23 of the consolidated version of the treaties on the EU and its functioning (ex art. 20 TEC) that only grants a very traditional, delegated «protection of the diplomatic and consular authorities.» However, the main reason why the rupture with the traditional model was never completed is given by the art. 20 (ex art. 17): «Citizenship of the Union shall complement and not replace national citizenship.» The Declaration on Citizenship of a Member State, annexed in 1992 to the Maastricht Treaty explicitly states: «wherever in the Treaty establishing the European Community reference is made to nationals of the Member States, the question of whether an individual possesses the nationality of a Member State shall be settled solely by reference to the national law of the Member State concerned» (GU C 191/1992). The goal is to limit controversy, but these precautions are actually the root of many unsolved problems and judicial hard cases as well. Let us explain why.

The provision of Article 20 does not imply subordination, but coexistence of various member states' nationality laws and regulations. Some even claim we face concurrent provisions. This means that member states enjoy a large area of discretion. Some effort has been made toward harmonisation in the realm of nationality law, but we still deal with very different regulations around Europe today (Schade 1995, De Groot 2002). Less that a decade ago, the Commission still claimed, on the basis of a study from 2000, that nationality laws converge, albeit with the period of legal residence required for applying for naturalisation ranging from 3 years in Belgium to 18 in Finland (Groenendijk, Guild 2000). Despite some converging trends - primarily the extension of ius soli and harmonisation of family reunification practices (Carrera 2006) - what we learn from recent surveys of citizenship policies in the European Union is that these are increasingly contested in domestic politics and may become a source of conflict between member states (Bauböck 2007, data and additional analyses are available at: www.imiscoe.org/natac). Thus, spontaneous convergence towards uniform norms is no longer a plausible expectation.

Moreover, the wording of Article 20 gives member states the possibility to influence or determine indirectly who is considered an EU citizen. The paradox is that there are, so to say, citizens of member states that are not EU citizens! For example, this is the case of the inhabitants of the Färø Islands who are technically Danes but not EU citizens, contrarily to the Danish inhabitants of Greenland. It might seem even more puzzling if we add that the inhabitants of the Dutch Antilles, residents in Aruba or in the French territories d'outre-mer are EU citizens.

Another interesting case is Spain: Spanish citizens who also have the citizenship of one of the twelve Latin-American states with which Spain has bilateral agreements, may or may not be EU citizens depending on residency. According to the Spanish Civil Code (art. 20), Spanish citizenship 
entailing EU citizenship is given by sole declaration on the basis of the ius sanguinis principle if one of the parents was born in Spain. This is the case of about 80000 Cubans, including Fidel Castro (De Groot 2004:7). In 2002, this problem was also raised for around 200000 British citizens of overseas territories. It is enough to mention the case of British overseas citizen Manijt Kaur, of Indian descent, born in Kenia in 1949, who claimed she had been stripped of her EU citizenship (ECJ 20 February 2001, Case 192/99 ECR I-1237).

These cases are not only the bitter fruit of the malfunctioning of the legal citizenship standard, but they also entail problems for the political standard. On one hand, it is clear that a large number of non-EU citizens living in the Union are under the obligation to observe European regulations, without having the possibility to vote for the Parliament. On the other hand, the fact that member states enjoy discretion when defining their national citizens also has a feedback effect on the design of the constitutional framework of the Union. For example, since one of the so-called "parameters of representation" is population size, the way "population" is defined (all residents, all citizens of member states, all nationals...) induces change in population size and hence the weight of a member state within the Union. It is enough to recall that Greece, Hungary, Ireland but also Italy and Spain have a considerable amount of expatriated citizens, while Germany and the Baltic States have a significant number of TCNs. Member states might therefore be interested in "increasing" their population. Needless to recall the fuss between Poland and Spain during the negotiations for the Constitution Draft, but one of the reasons why negotiations stalled in June 2007 was the Polish request that the damage in its population-size due to the Second World War should be taken into account when giving Poland its political weight in Europe today.

This text book example concerning the "parameters of representation" has also been raised in relation to Turkey. The ancient fear of the Turks was revived by claiming that the population size is such that, in the event of membership, the EU institutions would suffer "Turkification." This argument usually goes under the name of the "absorption capacity" of the EU, a criterion that was not part of the original Copenhagen agreement in 1993 and that has raised suspicions in Turkey over Europe's real intentions (Karlsson 2007). Another interesting case are the 900000 Romanian passports handed out during the last decade to people born in Moldavia.

In the recent history of the UK, something similar to an artificial population increase happened when UK citizenship entailing EU citizenship was extended to the population of Hong Kong in 1997 and to the citizens of British overseas territories in 2002. Of course, the use of member state legislation on nationality law is not totally unrestricted: it needs to observe international law, l'acquis communautaire and solidarity obligation (Gemeinschaftstreue). Still it is not clear what would have 
happened if Cyprus had not been accepted in the Union and Greece had extended its citizenship to all Greek Cypriots (Kotalakidis 2000: 299). The legal standard modelled on the principles of ius sanguinis and ius soli hence triggers new problems.

\section{Towards Residence-based Entitlement?}

In the wake of the Amsterdam Treaty, especially with its Title IV on the area of freedom, security and justice, some trends of denationalisation have been shedding new light on the idea of connecting citizenship to residency. On May 14 ${ }^{\text {th }}, 2003$ the Economic and Social Committee proposed the extension of European citizenship to non-nationals of member states on a criterion of residence. This led to the status of long-term residency for TCNs. At the Tampere Summit, in October 1999, the European Council added a new political objective: «the EU should ensure fair treatment of thirdcountry nationals residing lawfully on the territory of Member States and that a more vigorous integration policy should aim at granting them rights and duties comparable to those of citizens of the European Union» (Preamble 6). The result was the long-term residency status defined in the Directive 2003/109/CE from November 2003 (it does not include Denmark, Ireland and the UK on the basis of the Amsterdam Treaty and annexed protocols). According to this directive, its aim is to «bring the legal status of TCNs closer to that of the citizens of the Member States.»

In addition to this, EC case law is increasingly viewing the rights of third country nationals in one of the Member States as being much the same as those of EU citizens: Besides the Carpenter case, we should also mention the Hacene Akrich case from 2007, concerning the rights of a Moroccan national who had married a UK national, relying on Community law in order to secure his entry and residence in the UK. In its judgement on a reference from the High Court, the ECJ emphasized the need for the UK immigration authorities in considering the application of a third country national to be admitted to the UK to refer to Article $8 \mathrm{ECHR}$ on respect for family life. Those rights belonged, in the case in question, to both the third country national and to the EU citizen to whom he was married.

During the Convention on the Future of Europe and the Drafting of the Constitutional Treaty, NGOs sought to lobby for the Union citizenship to become residence-based. Even if this objective was not reached, the Article III-257(2) of the Constitutional Treaty, restated in art. 67 (2) of the consolidated version of the Lisbon Treaty (ex art. 61 TEC and ex art 29 TEC), commits the Union to frame a common asylum and migration policy which is «fair to TCNs.»

This development toward residence-based entitlement has been celebrated as a way to overcome some of the counter-efficient and paradoxical effects of the introduction of EU citizenship. Therefore many believed that the ius domicilii principle would somehow contribute to the bridging of 
the various standards on citizenship that I have been illustrating. There are at least three reasons why this has not happened and why it is not likely that the threes models can be linked this way.

First, from the legal viewpoint, there is no commonly shared or joint opinion on residencebased entitlement. This is clear from the polarization between the ECJ and other European institutions. The positions of the executive and judicial branches of the Union on this very issue are, indeed, incompatible. On one hand, the Council, along with the Commission and the Parliament, often addresses the problem of TCNs from a purely social stance. Long-term residency is hence sustained with the purpose of boosting social integration. On the other hand, the ECJ focuses on the problem from a typical legal viewpoint. With the Micheletti-case from 1992 (ECJ 7 July 1992, Case C-369/90 ECR F-4258), European case law departed from the effectiveness principle which rules international law. The effectiveness principle in international law is based on art. 5 of the Convention of the Hague, and was acknowledged in the 1955 Nottebohm ruling of the International Court of Justice, when it was established that "nationality is a legal bond, based on a social fact of linkage." Having the passport of a state is not enough to be able to claim to have that nationality. Citizenship hence depends on the "habitual residency." The reasoning of the ECJ has taken the opposite direction, following a more formal stance. Citizenship is not determined by effectual residency, but through formal status certification. According to the European Court of Justice, Mario Vincente Micheletti - an Argentinean dentist living in Spain with an Italian passport obtained iure sanguinis - could not be excluded from the rights to free movement and settlement granted by art. 21 (ex art. 19 TEC). In the name of nondiscrimination, European case law took a step away from connecting EU citizenship to domiciliation. This in turn has led to further problems (Davis 2005). The crucial problem that the legal standard of citizenship aims to resolve - the multiplication of incompatible yet judicially relevant positions ascribed to the same individual - finds no adequate solution within the current framework.

Secondly, from the political standpoint, assimilating the status of the EU citizen and that of the TCN does not address the question of the democratic deficit. What should be stressed, as far as ius domicilii is concerned, is that the principle of residency primarily seems to have the purpose of promoting social integration, through the reduction of discrimination between EU citizens and TCNs lawfully residing in the Union. It therefore responds most of all to a requirement of the social citizenship standard. The "democratic deficit" remains largely unaffected, because the political standard for assessing citizenship is seldom in the focus: Democratic deficit is usually discussed as if it did not concern the (legal) citizenship status. Therefore, we may claim that Europeanisation as denationalization has not entailed re-civification. 
In addition, art. 11 (4) of the consolidated version of the EU Treaties makes a provision for socalled "citizens' initiatives." In fact, a petition with one million signatures of "nationals of a significant number of member states", i.e., EU citizens (which equals $0,2 \%$ of the population in EU27), submitted to the Commission, may generate a legislative initiative. This innovation has been celebrated as a step toward greater citizenship involvement and participation in the European polity, but it turns out to be less than was bargained for. All in all, it only concerns cives optimo iure (EU citizens), whereas the TCNs are excluded. Even though Third Country Nationals lawfully resident within the EU amount to several millions, they are prevented from participating in bottom-up policy propositions to the Commission, and from the in-put legitimacy hereby created. In this way, the Lisbon Treaty adds an element of political discrimination that did not exist previously.

Finally, from the perspective of social integration, bringing closer the status of EU citizens and TCNs, does not seem to resolve the issue of social exclusion: An eventual overlapping between the legal, political and social situations of EU citizens and TCNs will only highlight another "layer" in the exclusion mechanism. It is likely that the "next generation" of marginalised individuals will be the category of illegal immigrants or sans-papiers, that today amount to around 8 millions individuals, even though exact figures are hard to establish (Rigo 2007).

\section{Bridging the Models: A Comprehensive Framework}

I suggest a model for bridging these three paradigms in order to shed new light on some crucial problems concerning promotion of transnational citizenship. In particular, this meta-model aims to give a rational standard for measuring the adequateness of proposed means for declared ends in today's institutional and scholarly debate. Hopefully, such a perspective can give a more adequate explanation to a series of problematic cases, offering better consultancy to policy makers.

This model builds on the argumentation we find in Aristotle's theory of citizenship in the third book of Politics. Here, the philosopher uses two different questions for introducing the institution of citizenship which, in his view, amounts to being in turn ruler and ruled: the first question is: what is the citizen? And the second question is: who is the citizen? These two key-queries, when adequately combined, offer a comprehensive model for citizenship. Such a model can be labelled "comprehensive" because it provides the dual or binary elements for a rational investigation into the matter. In other words, it becomes clear what exactly is at stake: To reflect on the nature and role of the citizen requires answering these $t w o$ queries (Bovero 2000). 
What is the citizen? is a question of substance and it concerns the essential feats and features that define the figure. By answering this question it is possible to distinguish the concept of citizenship from other, more or less analogous or closely related notions. Therefore, the first query helps us to indicate what kind of activity is connected to the status. Needless to say that for Aristotle, whose model of citizenship is essentially political, the main activities associated with the status are voting in assembly and participating in popular juries.

The second query, who is the citizen? is a matter of function correlated to the first issue. It refers to the quality or ability a person has to enjoy in order to be plausibly designated as a citizen. To answer this second question you need to have stipulated of what the citizenship activity consists. Thus, this second key-question stresses entitlement and its preconditions: who is entitled to access the status? For Aristotle, as for most Greeks of his time, only free, Athenian, adult men are eligible for various reasons that I will not be discussing here, but that are strictly linked to the voting and judging activity of the citizen.

These two key-queries form what I would like to call an equation with two unknowns. The interesting point is hence to set up the elements of the operation and its modus operandi; i.e., to establish whether it is plausible or reasonable that a person has to have the attribute $x$ in order to carry out the task or function $y$ of which citizenship consists.

Let us take the following example in order to show how this model works. It is meant to be particularly uncontroversial. If one takes Aristotle's definition of citizenship activity as equivalent to participation in public deliberation, it follows that a reasonable criterion for accessing citizenship status is the capacity of the person to execute that specific task. A precondition for that execution is, for instance, age. In order to become a citizen the person would need to have passed the ephebia, a test assuring maturity, which in Athens was commonly done at the age of twenty.

This binary combination-based model is interesting today since it provides a rational standard for discussing some of the normative assumptions according to which citizenship is bestowed. Some of these assumptions have become highly problematic, as in the case of the principle of ius sanguinis. It is important to stress, however, the reasons why this is so. For instance, if we posit that citizenship activity is to play an active role in the political community (which was the aforementioned stipulation taken from Aristotle), e.g. voting for representatives - like it is generally intended in European democracy - it becomes problematic to confer entitlement to citizenship on a ius sanguinis basis, since it is far from obvious that election ability is linked to the prerequisite of being born of certain parents.

This meta-model can be used in order to assess difficulties linked to the principle of ius domicilii or residence-based entitlement. Most of all, it opens a new perspective on the core problem: 
Namely, what we really need to determine today is who, when and under what conditions a person is a stakeholder in the European polity. A challenge, indeed, for European citizenship. The meta-model is, therefore, a device for applying the principle of affectedness - a key tenet of democratic theory, according to which people should have a fair say on decisions affecting them - and for determining appropriate constituencies for specific policies for which traditional, national citizenship has proved to be over- or under-inclusive (Hilson 2007).

\section{A Functional Device for Social Analysis}

If Europeanisation can be conceptualised as a «process of continuous changes in EU borders in the course of which the definition of a political and public space is constantly being redefined and transformed» (Scott, Bee, Scartezzini 2008: 146), we should look at the paradoxical and often unpredictable effects of the implementation of Europeanisation policies. It is likely that the meta-model suggested can enhance our comprehension of when, where and how the discourse on EU citizenship is unnecessarily blurred. However, the method proposed for bridging the three standards is not only intended for purposes of refining the instruments used in social analysis.

More importantly, the hope is that this method will provide a counterfactual grid in order to assess different public policies concerning citizenship. This is important because public policies can be viewed as key technologies of subjectivation since they have a feedback effect on the way individuals perceive themselves and their actions, which leads back to the question of nested citizenship and the identity of the European Union.

An interesting aspect involving the three standards of citizenship and TCNs in Europe concerns the recent shift in public philosophies of integration. Governments in countries with established immigrant communities are worried about "ethnic enclaves" (Britain), "communitarism" (France), or "parallel societies" (Germany); worries that are strongly associated with immigrants of Muslim origin. Grounded in perceiving dangers that range from structural unemployment to banlieux urban riots, some recent naturalisation policies stress "social citizenship" (integration) as a precondition for access to "legal citizenship" (naturalisation). Incidentally, it should be added that this conception of "social citizenship" and integration is different from, if not opposite to, previous accounts (Marshall 1950), because of the reversed causal mechanism behind the accent on individual effort and achievement.

Citizenship is therefore considered an individual entitlement, but not deriving from a structural condition of equal rights and opportunities. As a tool for integrating societies of heterogeneous origin, 
and therefore no longer attached to "ethnic" identity and Blut und Boden descent, (legal) citizenship is regarded as a form of recompense for those who have managed individually (but not necessarily on their own) to obtain social citizenship. The passport is held to be the reward for those who are not considered to pose a threat to the national community because they have sufficient income, can communicate in the dominant language, identify with the history of their host society, and subscribe to its public values.

The model advocated here, which is grounded in the tripartite citizenship, suggests ways of questioning this approach: On the basis of this method, it is warranted to ask why denying (legal) citizenship to long-term immigrants who fail to meet these criteria should diminish the presumed threats. There is convincing empirical material, especially from long-standing countries of immigration, that the enhancement of "citizenship" in terms of social integration effectively reduces the alienation from where sprouts of political radicalism and eventually violence might spring. However, experience does not show that waiting for (legal) citizenship can efficiently reduce such risks. It seems far more likely that frustration and alienation will become stronger when a socially marginalised group remains excluded from legal entitlement to political membership and representation.

Another example of how the tripartite citizenship standard can be bridged, and applied to current policing, concerns the new trend to add citizenship tests to the already widespread requirement of learning the dominant language. Such tests have recently been introduced in Austria, Denmark, Germany, Greece, the Netherlands, and the United Kingdom. They include questions about the country's history, constitution, and everyday culture and/or folklore. All sorts of arguments can be found in debates preceding the adoption of such measures, but the binary combination-based model advocated here is interesting because it provides a rational standard for the discussion of the normative assumptions on the basis of which citizenship is bestowed.

If citizenship activity consists of: (a) obeying the law of the land (legal citizenship standard enhancing rule of law); (b) taking an active part in the political community (political citizenship promoting legitimacy); (c) interacting fruitfully with other members of civil society (sociological model of citizenship advocating greater social cohesion), under what conditions is it plausible to confer this entitlement: knowledge of the language prevalently spoken? Does the person already have to be fluent or is future comprehension sufficient? Can acquaintance with holiday- or food habits be a necessary precondition for entitlement? Is the understanding of the constitutional arrangement compulsory? Can age, gender or health be considered derogatory conditions? Is any economic condition a pay off for any of these requirements? 
By applying this binary combination-based model it becomes easier to see why the prerequisite of having, for example, a high educational level is not in itself recommendable for conferring entitlement. There is a danger that difficult tests - that many nationals would probably fail - will make it harder for immigrants without secondary or university education to become citizens. This, in turn, corresponds to what many specialists in the field of citizenship studies are claiming. Bauböck and Ersbøll (2006), in particular, stress that while language skills might prove useful for social and political integration, the usefulness of the often far-fetched questions asked in citizenship tests is much less obvious.

Similar reasoning applies to the apparently utilitarian and economically-orientated approach prevailing in European labour migration policies, selecting - as part of the Lisbon strategy - highlyskilled or talented TCNs after labour market tests are carried out to check whether the post cannot be filled by nationals. This approach seems to be based on a questionable confidence of state authorities in their ability to determine the future needs of labour markets (Carrera 2006). Examples may be multiplied but the point has been made.

\section{Concluding Remarks}

Citizenship studies require less ambiguous tools for social analysis than those prevailing in literature. Very few attempts to overcome disciplinary divides have yet been made. Here, a scheme has been canvassed and a specific method for assessing current policies in the field of citizenship and migration has been fleshed out. The combination-based model provides a rational standard for discussing normative assumptions behind entitlement to citizenship. Is it plausible that a determinate personal capability is necessary in order to perform adequately the activity required from a citizen? If the answer is yes, this capability is sufficient basis for conferring citizenship (e.g. through naturalisation processes); otherwise, entitlement unsupported by aptitude is unwarranted.

This method can contribute to our understanding of the complex contemporary Europeanisation processes by shedding new light on transnational citizenship building and cross-state characterisation of appropriate constituencies for the stakeholders in Europe. 


\section{References}

Arts, W., Halman, L. (2004) (eds.) European Values at the Turn of the Millennium, Brill Academic, Leiden.

Barbalet, J.M. (1988) Citizenship, Rights, Struggle and Class Inequality, Open University Press, Milton Keynes.

Bauböck, R. (1997) 'Citizenship and National Identities in the European Union', in Integration durch Demokratie. Neue Impulse für die europäische Union, eds E. Antalosvsky, J. Melchior, S. PuntscherRiemann, Metropolis, Marburg, pp. 302-20.

Bauböck, R., Ersbøll, E., Groenendijk, K., Waldrauch, H. (eds.) (2006) Acquisition and Loss of Nationality, Policies and Trends in 15 European States, Vol. I Comparative Analyses, Vol. II Country Analyses, Amsterdam University Press, Amsterdam.

Bauböck, R. (2006) 'Who are the citizens of Europe?’, in Id. R., Ersbøll, E., Groenendijk, K. (eds.)

Acquisition and Loss of Nationality, Amsterdam University Press, Amsterdam.

Bellamy, R. (1994) 'Tre modelli di cittadinanza', in La cittadinanza. Appartenenza, identità, diritti ed D. Zolo, Laterza, Roma-Bari, pp. 223-242.

Bellamy, R. Castiglione, D. (eds.) (2004) Lineages of European Citizenship: Rights, Belonging and Participation in Eleven Nation-States, Palgrave Macmillan, London.

Bellamy, R., Castiglione, D., Shaw, J. (eds.) (2006) Making European Citizens. Civic Inclusion in a

Transnational Context, Macmillan, Palgrave.

Bodin, J. (1583) Six Books of the Commonwealth (Scientia, Aalen 1977).

Borgatta, E. \& M. (1992) ‘Citizenship' in Encyclopedia of Sociology, Macmillan, New York.

Boudon, R. \& Bourricaud, F. (1982) 'Citoyenneté' in Dictionnaire critique de la sociologie, PUF, Paris.

Bovero, M. (2000) Contro il governo dei peggiori: una grammatica della democrazia, Laterza, Roma.

Brubaker, R. (1992) Citizenship and Nationhood in France and Germany, Harvard University Press, Cambridge (Mass.).

Bulmer, M. \& Rees, A.M. (eds.) (1996) Citizenship Today. The Contemporary Relevance of T.H. Marshall, UCL Press, London.

Carrera, S. (2005) 'What Does Free Movement Mean in Theory and Practice in an Enlarged EU?', in European Law Journal, vol. 11, n. 6, pp. 699-721.

Carrera, S. (2006) 'Legal Migration Law and Policy Trends in A Selection of EU Member States. Briefing Paper', Directorate-General Internal policies. Policy Department C - Citizens' Rights and Constitutional Affairs, European Parliament, July 2006 (copies available at japap@europarl.europa.eu)

Colas, D. \& Emeri, C. (eds.) (1991) Citoyenneté et nationalité, PUF, Paris.

Cordini, G. (1998) Elementi per una teoria della cittadinanza, Cedam, Padova. 
Costa, P. (1994) 'La cittadinanza: un tentativo di ricostruzione archeologica', in La cittadinanza. Appartenenza, identità, diritti, ed D. Zolo, Laterza, Roma, pp. 47-92.

Dahrendorf, R. (1988) The Modern Social Conflict. An Essay on the Politics of Liberty, Weidenfeld and Nicolson, New York.

Davis, G. (2005) 'Any Place I Lay My Hat? or: Residence is the New Nationality', European Law Journal, vol. 11, n. 1, 43-56.

Delanty, G., Rumford, C., (2005), Rethinking Europe: Social Theory and the Implications of Europeanisation, Routledge, London.

Dollat, P. (1998) La libre circulation des personnes et citoyenneté européenne: enjeux et perspectives, Bruylant, Bruxelles.

Düring, I. (1966) Aristoteles. Darstellung und Interpretation seines Denkens, Winter, Heidelberg.

Ferrajoli, L. (1994) Dai diritti del cittadino ai diritti della persona', in La cittadinanza. Appartenenza, identità, diritti ed. D. Zolo, Laterza, Roma, pp. 263-292.

Garot, M.J. (1999) La citoyenneté de l'Union européenne, L'Harmattan, Paris.

Gerhards, J. (2008) 'Free to Move? The Acceptance of Free Movement of Labour and Non-discrimination in Europe', in European Societies, vol. 10, n. 1, pp. 121-140.

Germani, G. (1973) El concepto de marginalidad. Significado, raíces históricas y teóricas, con particolar referencia a la marginalidad urbana, Ediciones Nueva Visión, Buenos Aires.

Giubboni, S. (2007) 'Free Movement of Persons and European Solidarity', European Law Journal, vol. 13, n. 3, pp. 360-379.

Groenendijk, K. \& Guild, E. (eds.), (2000) Le status juridique des ressortissants de pays tiers résidents de longue durée dans un Etat membre de l'Union européenne, University of Nimega (April).

Groot, de G.R. (2002) 'Zum Verhältnis der Unionsbürgerschaft zu den Staatsangehörigkeiten in der Europäischen Union', in Europäisches Integrationsrecht in Querschnitt, ed P.C. Müller-Graf, Nomos, Baden-Baden, pp. 67-86.

Groot, de G.R. (2004) 'Towards a European Nationality Law', Electronic Journal of Comparative Law [online] Available at: http://www.ejcl.org/83/art83-4.html.

Groot, de G.R. (2006) 'Nationality', in Encyclopedia of Comparative Law ed. J.M. Smits, Edward Elgar, Cheltenham, pp. 476-492.

Guiguet, B. (1999) 'Citizenship and Nationality: Tracing the French Roots of the Distinction', in European Citizenship: An Institutional Challenge, ed. M. La Torre, Kluwer Law International, Den Haag, pp. 95-111. Hilson, C. (2006) 'EU Citizenship and the Principle of Affectedness', in R. Bellamy, D. Castiglione, J. Shaw (eds.) Making European Citizens. Civic Inclusion in a Transnational Context, Macmillan, Palgrave, pp. 5674.

Ifversen, J. (2002) 'Europe and European Culture - A Conceptual Analysis', in European Societies, (4) pp. 126. 
Isin, E.F. \& Turner, B.S. (eds.) (2002) Handbook of Citizenship Studies, Sage, London.

Janoski, T. (1998) Citizenship and Civil Society: A Framework of Rights and Obligations in Liberal, Traditional, and Social Democratic Regimes, Cambridge University Press, Cambridge.

Jenkins, R. (2008) 'The Ambiguity of Europe. "Identity Crisis" or "situation normal”?', in European Societies, vol. 10, n. 2, pp. 153-176.

Johnson, C. (1984) 'Who Is Aristotle's Citizen?', Phrónesis: a Journal for Ancient Philosophy, vol. 29, pp. 73-90.

Karlsson, I. (2007), Europa och turken, Wahlström \& Widstand, Stockholm 2007.

Kelsen, H. (1929) 'La naissance de l'Etat et la formation de sa nationalité. Les principes, leur application au cas de la Tchécoslovaquie', Revue de droit international, II.

Kelsen, H. (1945) General Theory of Law and State, Harvard Univ. Press, Cambridge (Mass.).

Krajewski, M. \& Rittstieg, H. (1986) 'German Nationality Law', in Nationality Laws in the European Union, ed. B. Nascimbene, Butterworths, London, pp. 357-387.

Köchler, H. (1999) Decision-making Procedures of the European Institutions and Democratic Legitimacy. How Can Democratic Citizenship be Exercised on the Transnational Level?, Report prepared for the Council of Europe, Innsbruck, pp. 1-23.

Lagarde, P. (19973) La nationalité française, Dalloz, Paris.

La Torre, M. (1999) (ed.), European Citizenship: An Institutional Challenge, Kluwer Law International, Den Haag.

Malmborg, M. af, Stråth, B. (2002) (eds.), The Meaning of Europe: Variety and Contention Within and Among Nations, Berg, Oxford.

Mann, M. (1996) 'Ruling Class Strategies and Citizenship', in Citizenship Today. The Contemporary Relevance of T.H. Marshall, eds. M. Bulmer \& A.M. Rees, UCL Press, London.

Marakov, A.N. (1962) Allgemeine Lehren des Staatsangehörigkeitsrechts, Kohlhammer, Stuttgart.

Marrus, M.R. (1986) Les exclus. Les réfugiés européens au XXè siècle, Calmann-Levy, Paris.

Marshall, T.H. (1950) Citizenship and Social Class and Other Essays, Cambridge University Press, Cambridge.

Mindus, P., (2006) '[Review of] European Values at the turn of the Millennium', in Teoria Politica, 2006:3, pp. 215-219.

Mossé, C. (1993) Le citoyen dans la Grèce antique, Nathan, Paris.

Offe, C., Preuss, U. (2006) 'The Problem of Legitimation in the European Polity. Is Democracy the Answer?' in C. Crouch, W. Streeck (eds.), The Diversity of Democracy, Elgar, Cheltenham.

Olsen, J.P. (2002) 'The Many Face of Europeanisation', in Journal of Common Market Studies, 40, pp. 92152.

Park, R.E. (1928) 'Human Migration and the Marginal Man', American Journal of Sociology (may).

Preuss, U.K. (2003) ‘Citizenship and the German Nation’, Citizenship Studies, vol. 7, n. 1, pp. 37-55. 
Price, P. J. (1997) 'Natural Law and Birthright Citizenship in Calvin's Case', Yale Journal of Law and the Humanities, Winter, pp. 73-129.

Radaelli, C.M. (2004) ‘Europeanisation: Solution or Problem?', in European Integration online Papers (EIoP), 8 (16).

Recchi, E. (2005) Migrants and Europeans: An Outline of the Free Movement of Persons in the EU, Academy of Migration Studies, Working Paper n. 38, Aalborg.

Recchi, E. (2006) 'From Migrants to Movers: Citizenship and Mobility in the European Union' in M.P. Smith, A. Favell (eds.), The Human Face of Global Mobility, Transaction Books, London.

Recchi, E. (2008) 'Cross-state Mobility in the EU: Trends, Puzzles and Consequences', in European Societies, vol. 10, n. 2, pp. 197-224.

Rigo, E. (2007) Europa di confine. Trasformazioni della cittadinanza nell'Unione allargata, Meltemi, Roma. Rosanvallon, P. (1992) Le sacre du citoyen. Histoire du suffrage universel en France, Gallimard, Paris.

Schade, H. (1995) 'The Draft European Convention on Nationality', Austrian Journal of Public and International Law, vol. 49, n. 2, pp. 99-103.

Scott, A., Bee, C., Scartezzini, R. (2008) 'Special Issue of European Societies - Cultural Spaces in Europe. Editors' Introduction', in European Societies, vol.10, n. 2, pp.143-145.

Shaw, J. (2007) The Transformations of Citizenship in the European Union. Electoral Rights and Restructuration of Political Space, Cambridge Univ. Press, Cambridge.

Sherwin-White, A.N. (1939) The Roman Citizenship, Clarendon Press, Oxford.

Sills, D. (1968) 'Citizenship', in International Encyclopaedia of the Social Sciences, Macmillan, New York. Turner, B.S. (ed) (1993) Citizenship and Social Theory, Sage, London.

Verwilghen, M. (1999) 'Conflit de nationalités. Plurinationalité et apatridie', Recueil des cours de l'Académie de droit international, vol. 277, Martinus Nijhoff, Den Haag. 
J ean Monnet European Centre of Excellence - University of Trento www.soc.unitn.it/poloeuropeo 